\title{
3D skin models in domestic animals
}

\author{
Laurent Souci and Caroline Denesvre* (1)
}

\begin{abstract}
The skin is a passive and active barrier which protects the body from the environment. Its health is essential for the accomplishment of this role. Since several decades, the skin has aroused a strong interest in various fields (for e.g. cell biology, medicine, toxicology, cosmetology, and pharmacology). In contrast to other organs, 3D models were mostly and directly elaborated in humans due to its architectural simplicity and easy accessibility. The development of these models benefited from the societal pressure to reduce animal experiments. In this review, we first describe human and mouse skin structure and the major differences with other mammals and birds. Next, we describe the different 3D human skin models and their main applications. Finally, we review the available models for domestic animals and discuss the current and potential applications.
\end{abstract}

Keywords: Skin, Explant, Skin equivalent, Reconstructed epidermis, Stem cells, Keratinocyte, Mammals, Birds

\section{Table of Contents}

1 Skin, a complex organ most dedicated to body protection and rich in stem cells

1.1 Structure, origin and functions

1.2 Major skin peculiarities in mammals and birds

1.3 Skin stem cells

2 Tools and techniques of 3D skin culture-decades of innovations for human

$2.13 \mathrm{D}$ versus $2 \mathrm{D}$ skin models

2.2 Reconstructed human epidermis (RHE)

2.3 Full-thickness skin (FTS) models

2.4 Complexification of 3D skin models: toward fully functional skins

3 3D skin models for livestock, poultry and companion animals: current and future

3.1 Skin explants in animals

3.2 Skin equivalents in animals
3.3 The future of 3D skin models in veterinary medicine

4. Conclusion

References

Most three-dimensional (3D) skin models have been developed in humans and were subsequently adapted to animals. This is mainly due to an easy accessibility to human skin specimens, its flat architecture, an active research for burn repairs, and the wide range of applications: e.g., pharmacology, modelling of skin diseases, and cosmetology. In addition, the strong societal pressure to reduce the use of animals for research purposes since the 1990s boosted the establishment of reliable reconstructed skin models as alternatives. Indeed, these novel 3D skin models made possible the ban on cosmetic testing on animals in the European Union in 2013 and in some other countries afterward. The first part of this review briefly describes the skin structure, functions, and skin stem cells. The second part describes the main methodologies of 3D skin production in humans since the last seventy years. The third part reviews the 3D skin models developed in livestock, poultry, and pets. As only few of these 3D skin models are currently available, we focus on potential future veterinary applications as a

*Correspondence: caroline.denesvre@inrae.fr

ISP, INRAE, Université de Tours, Equipe BioVA, Centre Val de Loire,

37380 Nouzilly, France

(c) The Author(s) 2021. This article is licensed under a Creative Commons Attribution 4.0 International License, which permits use, sharing, adaptation, distribution and reproduction in any medium or format, as long as you give appropriate credit to the original author(s) and the source, provide a link to the Creative Commons licence, and indicate if changes were made. The images or other third party material in this article are included in the article's Creative Commons licence, unless indicated otherwise in a credit line to the material. If material is not included in the article's Creative Commons licence and your intended use is not permitted by statutory regulation or exceeds the permitted use, you will need to obtain permission directly from the copyright holder. To view a copy of this licence, visit http://creativeco mmons.org/licenses/by/4.0/. The Creative Commons Public Domain Dedication waiver (http://creativecommons.org/publicdomain/ zero/1.0/) applies to the data made available in this article, unless otherwise stated in a credit line to the data. 
justification for the development of such 3D skin models. In our opinion, implementing 3D reconstructed skin models for poultry will be key to understand the role of skin differentiation in Marek disease virus biology.

\section{Skin, a complex organ most dedicated to body protection and rich in stem cells}

\subsection{Structure, origin and functions}

The skin is a flat organ covering the entire body and one of the largest in surface (about $2 \mathrm{~m}^{2}$ and 6 to $10 \mathrm{~kg}$ for an adult human) [1]. Skin has multiple functions essential to life, the major one being a barrier to protect the body from the environment. The skin limits (i) injuries and penetration of inert elements (chemicals, physical particles), microorganisms (protozoa, worms, bacteria, fungi, and viruses) and small insects, (ii) water loss of the body, and (iii) DNA damage induced by solar ultraviolet radiations. Additionally, the skin has sensory (nerves, vibrissae), thermoregulation (sweat gland, hair and feathers, and blood flow), and immune (Langerhans cells) functions. Moreover, skin appendages contribute to communication (i.e., cat with erect hairs, courtship display in birds) and to locomotion (flight feathers of birds, horse hoof).

The skin is constituted of three overlaid parts: the hypodermis, the dermis, and the epidermis, the latter being the outermost layer in contact with the air (Figure 1). The hypodermis also called the subcutaneous tissue, mostly formed of lipid cells, has a role as protective padding, insulation, and energy reservoir. The dermis consists of an extracellular matrix (ECM; fibers and glycosaminoglycans) and cells, mostly fibroblasts and immune cells. Fibroblasts deposit the collagen and elastic fibers that give the skin its elasticity. The dermis harbors blood vessels, nerves, glands, and skin appendages (e.g., hair in the hair follicle and the base of nails and claws).

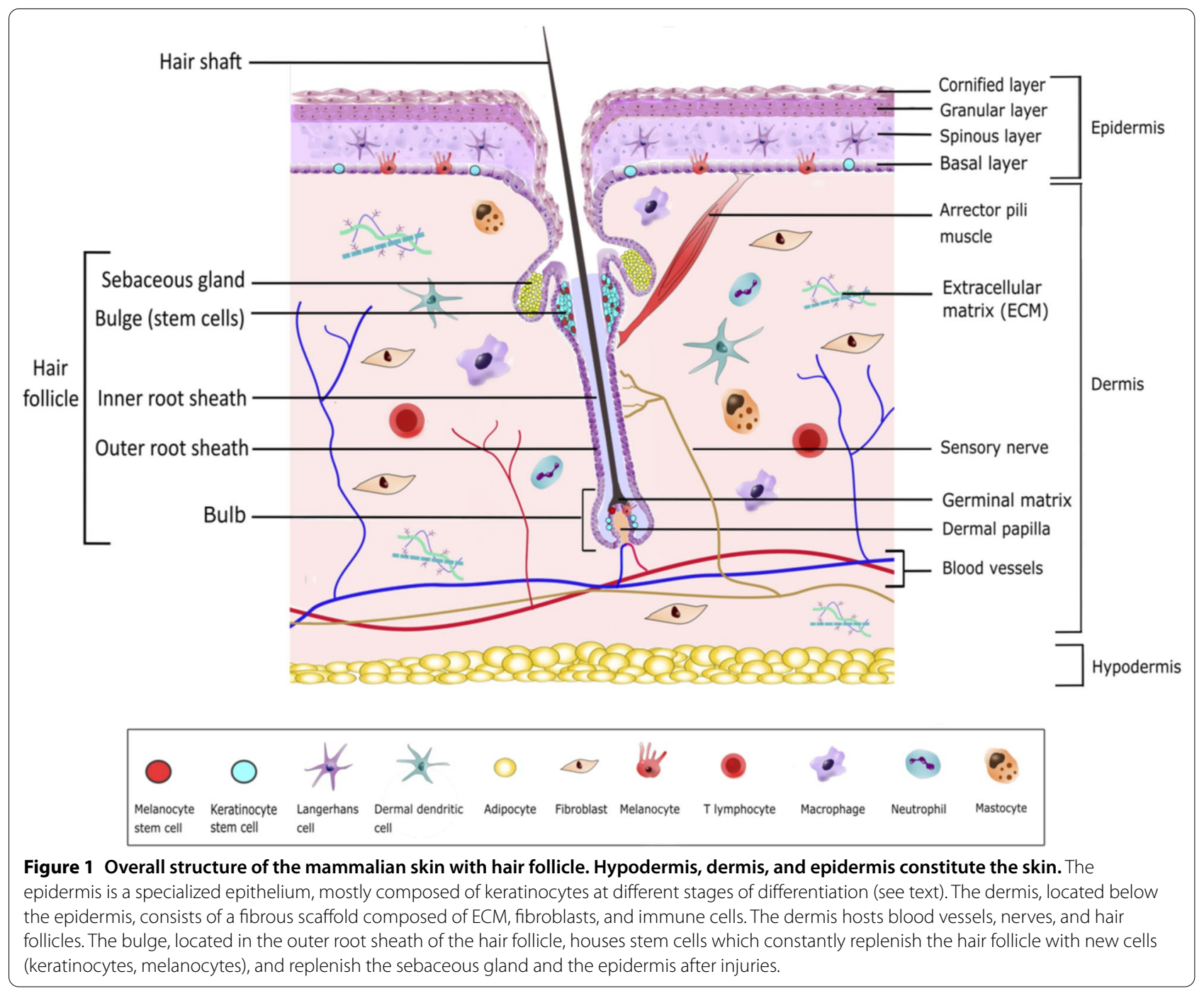


The complex structure of a hair follicle has led to consider it as a mini-organ. Glands and skin appendages will not be reviewed in detail in this article because most skin models are currently devoid of these complex structures. Indeed, current skin models are either constituted of an epidermis alone, or an epidermis associated with a dermis. Most of the thickness of the skin is formed by the dermis which is connected to the epidermis by a basal membrane. This basal membrane is composed of ECM proteins, and serves as a "proliferation-promoting platform" for the epidermis [2]. The epidermis is a stratified squamous epithelium mostly composed of keratinocytes (95\%). In mammals, these specialized epithelial cells are organized in four layers (from the most internal to the most external layer): the basal (or stratum germinativum), spinous (or stratum spinosum), granular (or stratum granulosum), and cornified (or stratum corneum) layers. Each layer contains keratinocytes at different stages of differentiation, from basal keratinocytes in the basal layer to corneocytes in the cornified layer. Basal keratinocytes are the only proliferative keratinocytes. At their ultimate stage of differentiation, keratinocytes become corneocytes. These cells are enucleated dead cells, resulting from a cell-death program referred to as cornification [3], during which they lose a large amount of water. Corneocytes are constantly shedding, a process called desquamation, and renewed by cells arising from underneath. In normal human skin, the complete differentiation of a keratinocyte and its progression from the basal layer toward the surface takes 40 to 56 days [4], depending on the individual's age (it is quicker in children and young adults). The age of the donors could therefore influence the quality of the skin used in in vitro models. In mouse, this differentiation process is of only 8 to 10 days [5]. In non-pathologic skin, the other $5 \%$ of epidermal cells are melanocytes, Merkel cells, and Langerhans cells. Melanocytes produce melanin which absorbs UV and give different colors to skin as well as hair or feathers [6, 7]. The number of each cell type per $\mathrm{mm}^{2}$ of skin and the ratios of different cell types in the human epidermis have been empirically estimated (reviewed in [8]). For example, the ratio of melanocytes or Langerhans cells to nucleated epidermal cells is of 1:36 and 1:53, respectively. This information is important for full skin reconstitution in vitro.

In a healthy skin, various immune cells have also been identified: antigen presenting cells [Langerhans cells, several subsets of dendritic cells (DCs), notably dermal DCs, and macrophages], and resident $\mathrm{T}$ cells [including regulatory $\mathrm{T}$ cells (Treg)], monocytes, mast cells, and neutrophils [9-11]. Langerhans cells are located in the epidermis, whereas the other immune cells are found in the dermis. Interestingly, immune cells in the skin maintain a subtle balance between a tolerogenic and an immunogenic state through innate and acquired immune response [12]. They can either detect invasive pathogens and induce a protective host response or maintain a tolerant environment towards foreign antigens. Keratinocytes, which produce Toll-like receptors, cytokines, chemokines, and growth factors can also orientate the immune response $[9,12]$. In mammals, anti-microbial peptides (i.e. B-defensins) as well as a variety of lipids present at the surface of the skin assist with microorganisms defense.

Healthy skin hosts various microorganisms on its surface, the skin microbiome. The composition and function of the skin microbiome has been studied in humans [13], as well as in dogs and chickens $[14,15]$. Interestingly, the skin microbiota differs from the gut microbiota in that the absence of skin microbiota (e.g., in germ-free mice) appears not deleterious for skin development and morphology [16], while the absence of gut microbiota negatively affects gut development.

The morphological aspect and thickness of the skin varies according to clades, species, race, and even genders, age, and body location. In humans, the skin is thick up to several $\mathrm{mm}$ over the sole of the feet in adults. In domestic mammals, the haired skin is thickest over the dorsal surface of the body compared to ventral region [17]. The epidermis is naturally thicker in surfaces that need enhanced protection [17]. Similarly, the stratum spinosum of dogs' footpads may contain up to 20 layers whereas it is made of only 1 or 2 layers in haired skin [17].

The skin components are coming of different embryological origins: the dermal fibroblasts originate from the mesoderm and the neural crest while the epidermal keratinocytes originate from the ectoderm [18]. Melanocytes are derived from the neural crest [19]. Langerhans cells originate from a subpopulation of bonemarrow CD34+-derived cells expressing the skin homing receptor cutaneous lymphocyte antigen (CLA) [20]. Langerhans cells may persist by local-self renewal [21]. Epidermal structures, such as different types of glands (i.e., sweet glands, sebaceous glands) and skin appendages (i.e., hair, feathers, nails, claws), form via cell-cell interactions with dermal fibroblasts [18, 22].

\subsection{Major skin peculiarities in mammals and birds}

The overall skin structure is well conserved across different mammalian species and body sites [2], although in the interfollicular epidermis, the number of stacked cells in a layer can vary according to the species. For example, the stratum spinosum has 1 or 2 cell layers in the haired-skin regions of mice, dogs, and cats, and up to 4 in humans, as well as in large animals [17]. The main differences between humans and most domestic and laboratory 
mammals concern the appendages: hair forming a fur, feathers a plumage, presence of vibrissa with tactile function in some domestic animals (e.g., cats and dogs). Hair and feathers are constantly shed and renewed, according to a cycle. The different phases of hair and feather follicle cycles are variable according to the species. The duration of the growth phase (or anagen) which is 4 to 7 years for the hair of human scalp or human male beard, is only of a few weeks in mouse.

Birds skin presents several differences when compared to mammals' skin. First, the skin is usually thinner and accommodates feather follicles, the homologues of hair follicles. The main difference between avian and mammalian epidermis is the absence of a granular layer involving filaggrin in birds [23]. Another characteristic of avian keratinocytes is the presence of lipid droplets in their cytoplasm, absent in mammals' keratinocytes [24, 25]. Importantly, numerous keratinocyte markers described in mammals (e.g., like K5/K14 keratins pair and involucrin) are conserved $[25,26]$. In contrast to mammals, melanocytes usually inhabit only the feather follicles and not the interfollicular epidermis in birds [27]. The silky chicken is an exception, with melanocytes populating also the dermis and connective tissues [27, 28]. Birds have a unique sebaceous gland, named uropygial, located dorsally at the base of the tail [28], while mammals have a hair follicle associated with two sebaceous glands, which are required for the emergence of the hair shaft [29]. Lastly, besides feathers, birds show two major hard skin appendages, the scales of the legs and feet, and the beak [28]. Cysteine rich proteins arranged in pleated sheets named corneous beta-proteins (CBP) constitute hard appendages of birds and reptiles (for review see [30]) and have no orthologues in mammals, of which the hair shaft and claws are formed by a special set of keratins [31].

\subsection{Skin stem cells}

Due to its composition, its constant renewal and the need of repair after wounds, the skin hosts different types of stem cells (or progenitors): tissular and multipotent stem cells. Stem cells are located in interfollicular skin and mostly in hair or feather follicles [32-34].

Interfollicular epithelial stem cells reside within the basal layer in mammals [33]. Two types of basal keratinocytes have been described: stem cells and transit amplifying keratinocytes, the second displaying a limited capacity of division [35]. These self-renewing cells adhere to the basal membrane through integrins/laminin interactions. Integrins are considered as good markers for these cells. Factors secreted by dermal fibroblasts (such as insulin-like-growth factor, fibroblast growth factor 7 , fibroblast growth factor 10 , and epidermal growth factor receptor ligands) promote basal keratinocytes' proliferation [34]. Basal keratinocytes express keratin 5 and keratin 14 [33]. When basal keratinocytes detach from the basal membrane and move upward, a process called delamination, they lose their proliferating property and start to differentiate and express keratin 1 and keratin 10. Basal keratinocytes isolated from the epidermis are able to propagate in vitro for several generations [36]. In fact, only $10 \%$ of human basal keratinocytes from the interfollicular epidermis and the hairless skin (soles) are stem cells and able to form foci that give rise to an epidermis in culture [35]. The interfollicular epidermis reservoir is located in the upper part (the bulge) of the outer root sheath of the hair follicle [37] (see Figure 1). Basal keratinocytes from domestic mammals (dog [38, 39], cat [40], horse [41, 42], sheep [43, 44], rabbit [45], and chicken [46]) have also been isolated and propagated in culture. Chicken basal keratinocytes express p63, a keratinocyte stem cell marker found in mammals [46]. Interestingly, proliferative keratinocytes, comparable to basal-like keratinocytes can be derived from embryonic stem cells in human, mouse, chicken $[26,47,48]$, or from induced pluripotent stem cells or iPSC, in horse [49].

Interfollicular dermal stem cells have also been identified in mouse and human skin [50]. These cells are important for dermis renewal and epidermal homeostasis regulation. It is important to note that these cells are multipotent cells and can differentiate into other cells of mesodermal and neural lineages [50].

After being hypothesized for a while, stem cells were also discovered in the hair follicle, predominantly in the bulge area [32] and in the dermal papilla [51]. There are two predominant types of stem cells in the bulge region: self-renewable cells and multipotent cells [52, 53] (for review see [54]). The former allows the renewal of the hair follicle and sebaceous gland, but also contribute to re-epithelialization of the epidermis during wound repair [55]. The latter are the hair follicles-associated pluripotent cells (HAP cells), which have the ability to differentiate into other cell types (i.e., nerve cells, glial cells, smooth cells) [56]. A characteristic of stem cells is that they remain in a prolonged quiescent state and are activated in response to hair renewal or skin injury. Different stem cells with have also been identified in the upper part of the hair follicle (isthmus and junction zone) [57]. Stem cells of the follicle hair bulge region have been identified in different mammalian species: dog [58-60], sheep [61], and pig [62]. In birds, epithelial stem cells are located in the collar bulge of the feather follicle above the dermal papilla [63]. In mammals, the bulge also harbors melanocytes stem cells [64], which in the human scalp have a shorter lifespan than hair stem cells, as they are programmed for around 20 hair cycles (D. Dhouailly, personal communication). Melanocyte stem cells serve 
as a reservoir for hair and skin melanocytes [6]. In birds, the melanocytes stem cells are located in an orthologous region of the feather follicle and serve only as reservoir for the feather melanocytes [7].

The dermal papilla, which is known to induce hair follicle [65], is located at the base of the hair follicle, and hosts mesenchymal stem cells. These cells are another source of iPSC [51]. Such cells were isolated in horse [66]. In chicken, comparable cells were also isolated in the dermal papilla of the feather follicle [67]. Interestingly, hair follicles constitute an important source of stem cells for regenerative medicine in mammals due to their easy accessibility. Moreover, basal keratinocytes and dermal fibroblasts are key cells for the development of skin equivalents.

\section{Tools and techniques of 3D skin culture- decades of innovations for human \\ $2.13 \mathrm{D}$ versus $2 \mathrm{D}$ skin models}

Numerous human skin models have been developed in the last 70 years, from skin explants cultivated ex vivo to in vitro reconstitution of skin equivalents or bioprinting techniques. One of the first mammalian skin model was developed by Medawar in 1948 [68]. It consisted of ex vivo skin cultures directly obtained from biopsies (rabbit, human). Quickly, in the 1950 's, these preliminary skin explant models were overshadowed by the advent and standardization of 2D cell culture methods. 2D models, are monolayer cells cultured on a solid surface under regular physico-chemical conditions. 3D models involve co-cultivation of the cells in three dimensions (in a spheroid or others volumes) in a way that they proliferate and interact with each other horizontally and vertically within an extracellular environment [69]. Despite its limits, the use of conventional 2D cell culture has prevailed for a long time to study different types of skin cells (keratinocytes, fibroblasts, melanocytes...) [1, 70]. It is only in the late 1970 's that 3D skin models saw a renewal thanks to Howard Green [36, 71]. 3D culture allows to obtain well differentiated cells and to co-cultivate different cell types together (e.g. keratinocytes associated with fibroblasts [72], with or without melanocytes [73, 74]). Moreover, it offers more possibilities than 2D culture by allowing to conduct more elaborate studies and in a wider range of applications (reviewed in $[1,75]$ ). Indeed, with 3D models, various factors can be explored: (i) Environmental factors, such as spatial orientation and mechanical forces [76]; (ii) Physiological factors such as gradient of nutrients, gases (e.g., $\mathrm{O}_{2}$ with normoxia or hypoxia zones), or signalling molecules [1] and (iii) Interaction factors, such as cell-to-cell, cell-to-ECM, and cell-to-environment (like air) interactions [77]. In addition, 3D tissue cultures lead to material with an architecture close to real skin and provide better prediction of in vivo results. These models give also more accurate results for drug testing than 2D cell cultures, for which the results were increasingly questioned [78]. In addition, reconstructed skin turned out as an alternative to animal experimentation, notably for testing cosmetic products, transdermal drug delivery [79], toxicological assays [78], and UV effects [80]. Reconstructed skin has therefore emerged as a potent cost-effective, practical, and more ethical solution in response to the increasing demand for skin testing. In the last 30 years, extensive research has been conducted for human skin, from which numerous innovations and models have emerged. These models have various levels of complexity depending on the type of supports used, the number of cell types involved, and their positioning. The main human and mouse 3D skin models are listed in Table 1 and the principles to obtain some of them are described in the following paragraphs.

\subsection{Reconstructed human epidermis (RHE)}

Human epidermis can be reconstructed (Figure 2) by cultivating keratinocytes on a support: (i) an acellular de-epidermized (aDED) matrix, (ii) inert filters, or (iii) a biomaterial structure forming a hydrogel or a lattice (Table 1). The aDED matrix was the first support utilized to produce a RHE exhibiting a cornified layer on its surface [81, 82]. To achieve this, primary keratinocytes isolated from human biopsies are seeded onto an aDED and allowed to differentiate for 2 weeks at the air-liquid interface (ALI) [81, 83]. Similar reconstructed epidermis (RE-aDED) are also developed for mouse [84]. Prunieras' discoveries opened the way for the intensive development of in vitro epidermis reconstructive methods. Indeed, in most RHE models, primary keratinocytes are isolated from a donor and cultured as a monolayer to be amplified. Keratinocytes are next seeded onto a matrix support to allow their adhesion and proliferation. This support is subsequently lifted to the ALI to bring keratinocytes in contact with air. In about 2 weeks, the differentiation and stratification of keratinocytes results in a multilayered stratified epidermis similar to that found in vivo (reviewed in $[85,86]$ ).

The second technique to produce RHE is a protocol using a support, a dermal substitute (DS), consisting of biomaterials only (e.g., collagen, alginate, hyaluronic acid, fibrin, etc.) (reviewed in [87]). The chosen biomaterial is often structurally similar to natural constituents of the extracellular matrix [88]. RHE-DS originated from the landmark study of Tinois [89], in which the support synthesis implies the crosslinking of collagens layers (with human collagen IV on the top). Collagen IV, the major in vivo component of the basal membrane, appeared to be a great substrate 
Table 1 Major 3D skin models in humans and mice

\begin{tabular}{|c|c|c|c|}
\hline Type of models & Species & Specificities & References \\
\hline Skin explants cultivated ex vivo (from biopsies) & Mouse & $\begin{array}{l}\text { Skin explants cultured on chick chorioallantoic membrane } \\
\text { (CAM) }\end{array}$ & [22] \\
\hline $\begin{array}{l}\text { Reconstructed human epidermis: on an acellular de-epider- } \\
\text { mized dermis (aDED) support }\end{array}$ & Human & \multirow{2}{*}{$\begin{array}{l}\text { Primary keratinocytes cultured onto an aDED to reconstruct } \\
\text { an epidermis. The keratinocytes being differentiated } \\
\text { through ALI }\end{array}$} & {$[81,83]$} \\
\hline $\begin{array}{l}\text { Reconstructed mouse epidermis: on an acellular de-epider- } \\
\text { mized dermis (aDED) support }\end{array}$ & Mouse & & [84] \\
\hline Reconstructed human epidermis: on plastic filter support & Human & \multirow{2}{*}{$\begin{array}{l}\text { Keratinocytes cultured at ALI on an inert surface (e.g. polycar- } \\
\text { bonate insert filter) }\end{array}$} & {$[91,92]$} \\
\hline Reconstructed mouse epidermis: on plastic filter support & Mouse & & [94] \\
\hline $\begin{array}{l}\text { Reconstructed human epidermis: on a dermal substitute } \\
\text { made of biomaterials }\end{array}$ & Human & $\begin{array}{l}\text { Seeding of keratinocytes on a dermal substitute made of } \\
\text { biomaterials (collagen, hyaluronic acid, alginate...). A mul- } \\
\text { tilayered epidermis is obtained following the differentiation } \\
\text { of keratinocytes at ALI }\end{array}$ & {$[89,95]$} \\
\hline \multirow[t]{2}{*}{$\begin{array}{l}\text { Full thickness skin: on dermal substitute made of biomateri- } \\
\text { als and populated with fibroblasts }\end{array}$} & Human & $\begin{array}{l}\text { Seeding of keratinocytes on a living dermal substitute (colla- } \\
\text { gen mixed with fibroblasts). A multilayered skin equivalent } \\
\text { is obtained following the differentiation of keratinocytes } \\
\text { at the ALI }\end{array}$ & [99-101] \\
\hline & Mouse & $\begin{array}{l}\text { Mouse skin epidermis model. Mouse keratinocytes cultured } \\
\text { at ALI on a living dermal substitute (type-I collagen with } \\
\text { murine dermal fibroblasts) }\end{array}$ & [102] \\
\hline $\begin{array}{l}\text { Full thickness skin: } \\
\text { DED populated with fibroblasts }\end{array}$ & Human & $\begin{array}{l}\text { Keratinocytes seeded on a DED populated with fibroblasts } \\
\text { and cultured at ALI }\end{array}$ & [97] \\
\hline $\begin{array}{l}\text { Full thickness skin: combining a DED populated with fibro- } \\
\text { blasts }\end{array}$ & Human & $\begin{array}{l}\text { Keratinocytes seeded on a DED populated with fibroblasts } \\
\text { and cultured at ALI }\end{array}$ & [98] \\
\hline Complex Full thickness skin: pigmented models & Human & Skin equivalent additionated with melanocytes & [121] \\
\hline Complex Full thickness skin: skins diseases related models & Human & Psoriasis or melanoma models & {$[123,127]$} \\
\hline Immunocompetent 3D skin equivalent & Human & $\begin{array}{l}\text { 3D skin model comprising of: dendritic cells (incl. Langer- } \\
\text { hans cells) or T-cells }\end{array}$ & {$[120,123-125]$} \\
\hline Full thickness skin: reconstituted from immortalized cells & Human & $\begin{array}{l}\text { 3D skin culture techniques using immortalized keratinocytes } \\
\text { and fibroblasts to produce a multilayered human skin } \\
\text { equivalent }\end{array}$ & {$[109,110]$} \\
\hline Full thickness skin: reconstituted from iPSCs-derived cells & Human & $\begin{array}{l}\text { Multilayered epidermal structure reconstituted from human } \\
\text { keratinocytes and fibroblasts cells derived from iPSCs }\end{array}$ & [113] \\
\hline Full thickness hair-bearing skin: organoid system & Human & $\begin{array}{l}\text { Multilayered epidermal structure exhibiting hairs reconsti- } \\
\text { tuted thanks to an organoid system }\end{array}$ & [117] \\
\hline 3D Skin obtained by bioprinting & Human & $\begin{array}{l}\text { Automated process used to overlay sheets of cells to obtain } \\
\text { a complex skin architecture }\end{array}$ & [129] \\
\hline Skin-on-chip systems & Human & $\begin{array}{l}\text { Technology combining reconstructed skin tissues with } \\
\text { microsystems }\end{array}$ & [132] \\
\hline
\end{tabular}

for keratinocytes, favoring both cell proliferation and anchoring to the dermal substitute support. With this method, a well-organized multilayered RHE with a structured basement membrane is obtained. This model was standardized, scaled up, and produced at factory level, leading to EpiSkin ${ }^{\mathrm{TM}}$ product (L'Oréal), one of the first reconstructed skin validated for in vitro corrosivity testing and irritation testing of chemicals (reviewed in [90]). This model has taken a step forward in reducing animal testing for chemicals and legitimated the high potential of reconstructed 3D skin models.

Culturing keratinocytes onto acellular inert filter supports is another alternative to produce RHE. Polycarbonates filters were first tested by Rosdy et al. [91]. With this support, a well differentiated and multilayered skin
RHE and reconstructed mouse epidermis RME) were obtained, similar histologically to real skin [91-94]. This method was at the origin of a skin production factory, supplying a novel reconstructed skin (SkinEthic ${ }^{\mathrm{TM}}$ ), initially for testing cosmetics and later for testing chemical corrosion and irritation [93].

RHE models are commonly used to evaluate cosmetics or topical drug products for irritation, phototoxicity (response to UV-lights) [95], corrosion, or skin sensitivity (due to immune reaction) [96]. Permeation of the skin and efficacy of cosmetic products are also determined on RHE skin models [92]. 


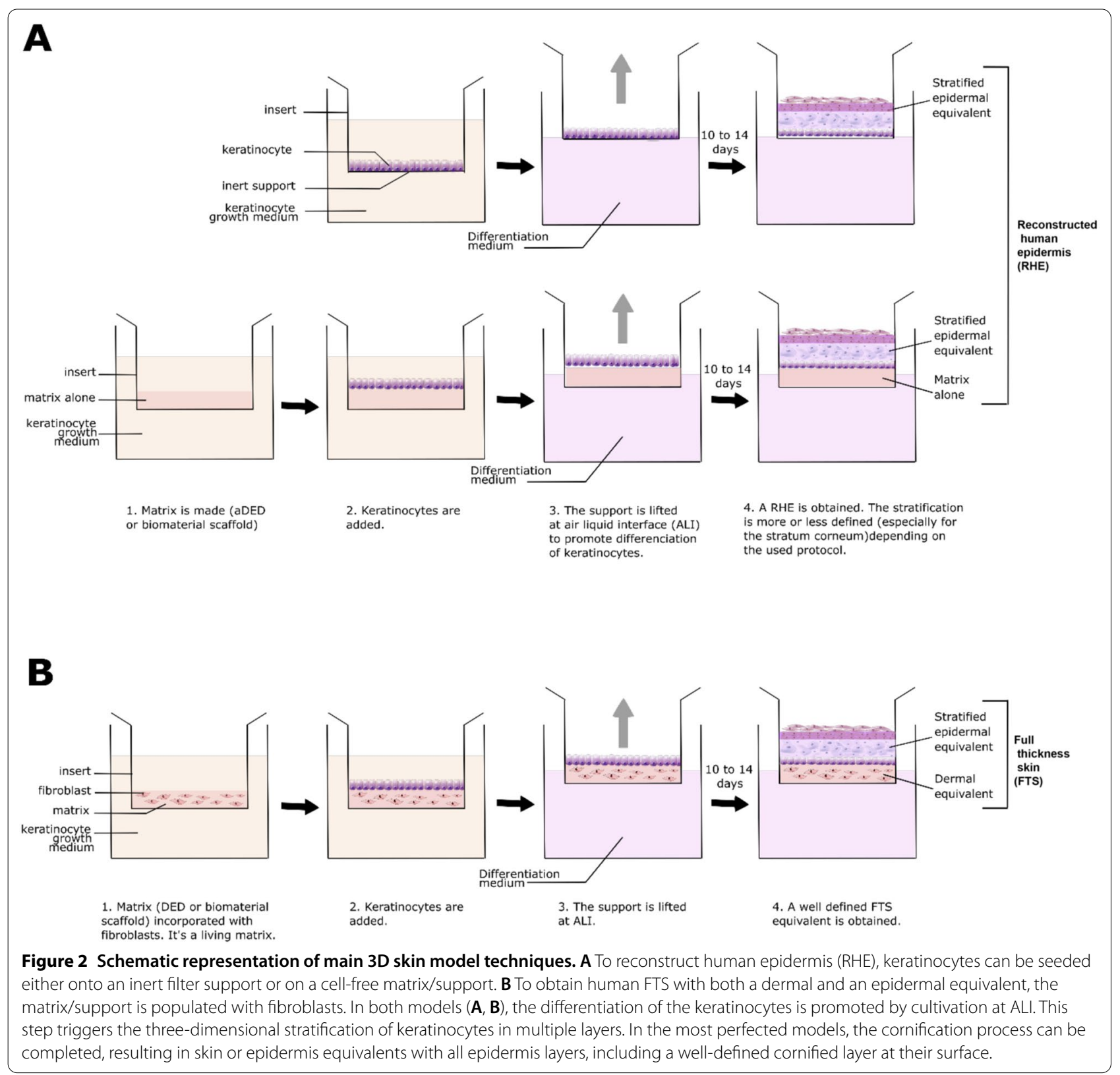

\subsection{Full-thickness skin (FTS) models}

Going one step further, human FTS models can be produced using a living dermal equivalent populated with fibroblasts (Fig. 2). As such, the reconstituted 3D skin possesses two compartments: one dermal compartment with fibroblasts and one epidermal compartment with keratinocytes. The living dermal substitute can be produced either on (i) a DED matrix $[97,98]$ or (ii) a biomaterial scaffold support, in which fibroblasts are incorporated. Referring to the method of Bell [99, 100], human and mouse FTS can be produced using a fibroblast-populated collagen lattice [101, 102]. The collagen scaffold retracts when submerged in a defined medium forming a solid lattice. The integrated fibroblasts are, in the Bell's model, restricted to the retracted biomaterial [103]. The matrix contraction occurs due to physical forces exerted by incorporated fibroblasts [104, 105]. A variety of biomaterial has also been used in combination with fibroblasts to produce FTS [106]. These 3D scaffold matrices are presumed to be similar to the real dermal tissue at functional, structural, and mechanical levels [1, 107]. Moreover, the proliferation of fibroblasts is, in fact, inhibited in the dermal equivalent due to retrocontrol mechanisms and to biochemical confinement [103, 108]. 
FTS can be reconstructed with primary cells as described above, but also with immortalized cells or skin cells derived from stem cells (iPSC or others). Indeed, one major issue was to reconstitute $3 \mathrm{D}$ skin independently of skin donors and primary cells. Physiologically relevant FTS was obtained using human TERT-immortalized keratinocytes and fibroblasts (TERT-HSE) [109]. Reconstruction of well-differentiated skin was also established using immortalized primary human foreskin keratinocytes [110]. Pioneer studies demonstrated that human and mouse keratinocytes obtained from embryonic stem cells were usable for full reconstruction of pluristratified epidermis [47, 48]. More recent studies have shown that iPSC can be differentiated into keratinocytes [111, 112], fibroblasts [113], or melanocytes [114]. Basal membrane obtained with iPSCs-derived fibroblasts were proven to exhibit similar characteristics to primary fibroblasts (review in $[115,116])$. Itoh et al. obtained for the first time a well differentiated full-thickness 3D skin equivalents using exclusively human iPSC-derived keratinocytes and fibroblasts [113]. Recently, hair-bearing human skin was reconstructed by using human pluripotent stem cells only, thanks to an organoid system [117].

\subsection{Complexification of 3D skin models: toward fully functional skins}

Current challenges are now focusing on engineering even more physiologically relevant skin models (reviewed in [118]). This complexification can be made by incorporating different types of skin components such as vasculature [119], appendages (hair follicles, glands), pigmentation, innervation, immune cells [120], or hypodermis. Reconstructed human pigmented epidermis (RHPE) possessing melanocytes cells is available [121] and commercialized (e.g., SkinEthic RHPE ${ }^{\mathrm{TM}}$, MelanoDerm ${ }^{\mathrm{TM}}$ ). Many other improvements have been obtained by incorporating other cell types. For example, fat sub-cutaneous hypodermis was reproduced by adding adipocytes [122], and reconstructed immune-competent skin was obtained (see Table 2) following the addition of T-cells [123], Langerhans cells [124, 125], or mDCs [120]. The development of skin disease models is also the object of many efforts (reviewed in [126]), like in vitro skin cancer models (constituted with melanoma cells and/or melanocytes [127]) or psoriasis models [123]. These models often required optimized immuno-competent $3 \mathrm{D}$ skin due to the complex cross-talk involved between various immune cell types and cytokines [128].

The elaboration of the next generation of 3D skin models benefits from the development of more advanced technologies. For example, bioprinting is one promising solution that had emerged over the last decade. Skin reconstitution by bio-fabrication can be made according to three techniques: (i) Inkjet-based, (ii) pressureassisted, or (iii) laser-assisted bioprinting (reviewed in [129]). Bioprinting is an automated approach consisting in the deposition of cells and biomaterials (e.g., bioinked hydrogels) so as to imitate very closely the real skin structure [130]. This technique is highly reproducible and allows a precise positioning of the cells. In the past years, a broad range of biomaterials has been utilized as "bio-ink" to produce full thickness skins: natural polymers including collagen, gelatin, alginate, and synthetics polymers including polyethylene glycol and poly lactic-co-glycolic acid [130]. The expansion of bioprinting skin manufacturing has rendered possible the production of very complex 3D skin exhibiting, for example, both vasculature and lymphatic capillaries [131]. The last improvement in these models is the development of skinon-chip models, a technology combining cell/tissue with microsystems (see review of [132]).

\section{3D skin models for livestock, poultry and companion animals: current and future}

There is a huge gap between 3D skin research for human and for veterinary purposes, both in abundance and in complexity. Although skin models were first conceptualized in animals, animal skin models are no longer considered relevant for use in the pharmaceutical and cosmetic industry since the development of human 3D skin models. As a result, the number of animal 3D skin models available nowadays is very limited [133]. These models are either old models developed for human purposes (notably explants) or novel models developed for veterinary medicine or comparative biology. Nowadays, animal skin model development is focusing on animal companion species known to have predispositions for skins diseases, like dogs. The available 3D skin models related to livestock (pig, cow, sheep, rabbit), poultry (chicken), and companion animals (dog, horse) are listed in Table 2.

\subsection{Skin explants in animals}

Skin explants were reported in rabbit, pig, cow, and dog as referenced in Table 2. Initial skin explants were developed in the 1940s and abandoned in favor of monolayer cell cultures. A resurgence of interest appeared with Kondo's study using rabbit ear skin biopsy as split thickness skin explant which contains an epidermis with an upper dermis portion. This model can be cultured stably up to 12 weeks in a diffusion chamber [134]. It opened the way to skin explants in other farm animals such as sheep, cow, or pig. Epidermis explant from bovine hoof was cultured at the ALI and remained viable in shortterm culture [135]. Interdigital skin explant from ovine hoof cultivated in anaerobic conditions was viable during 


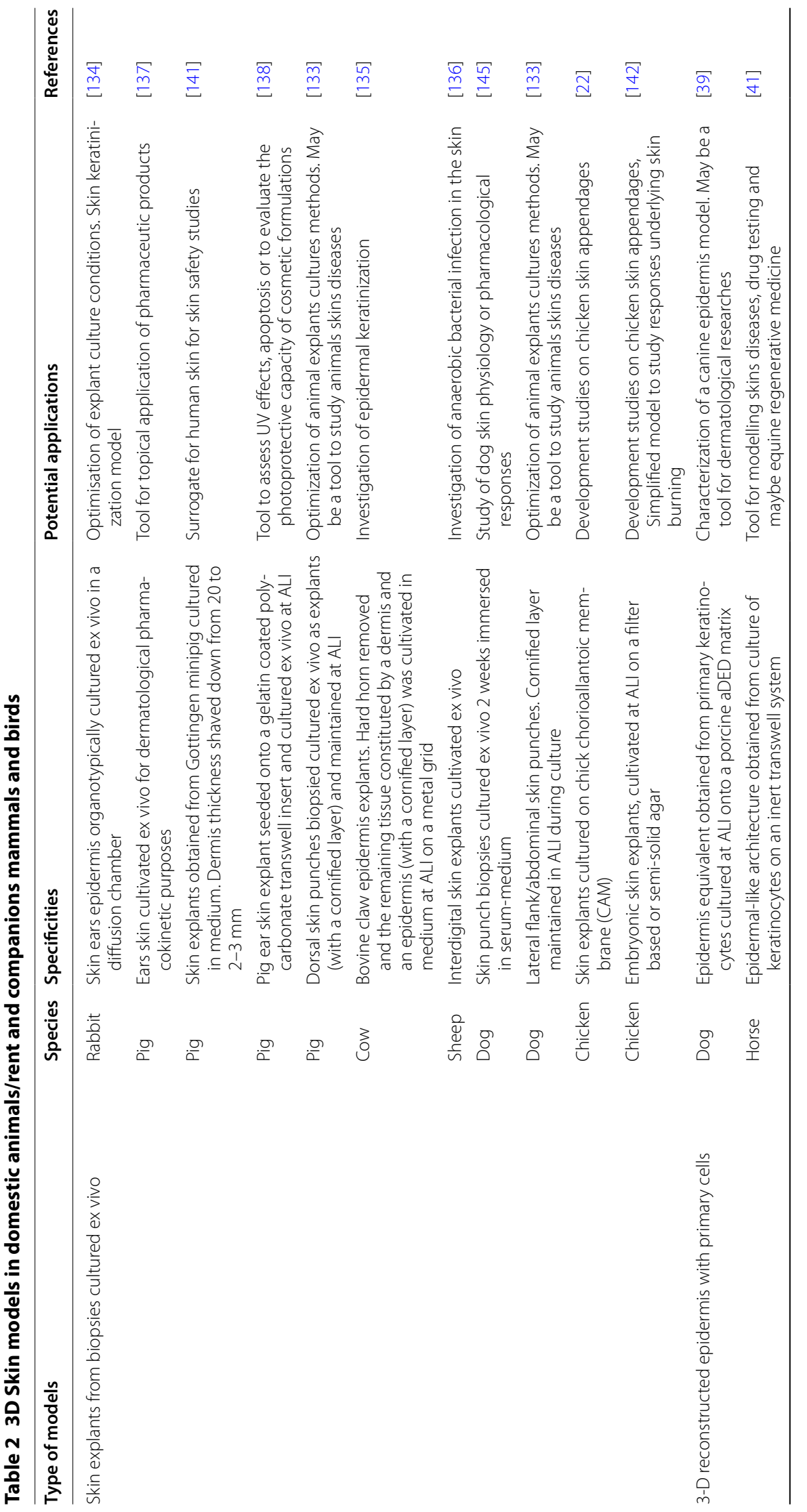




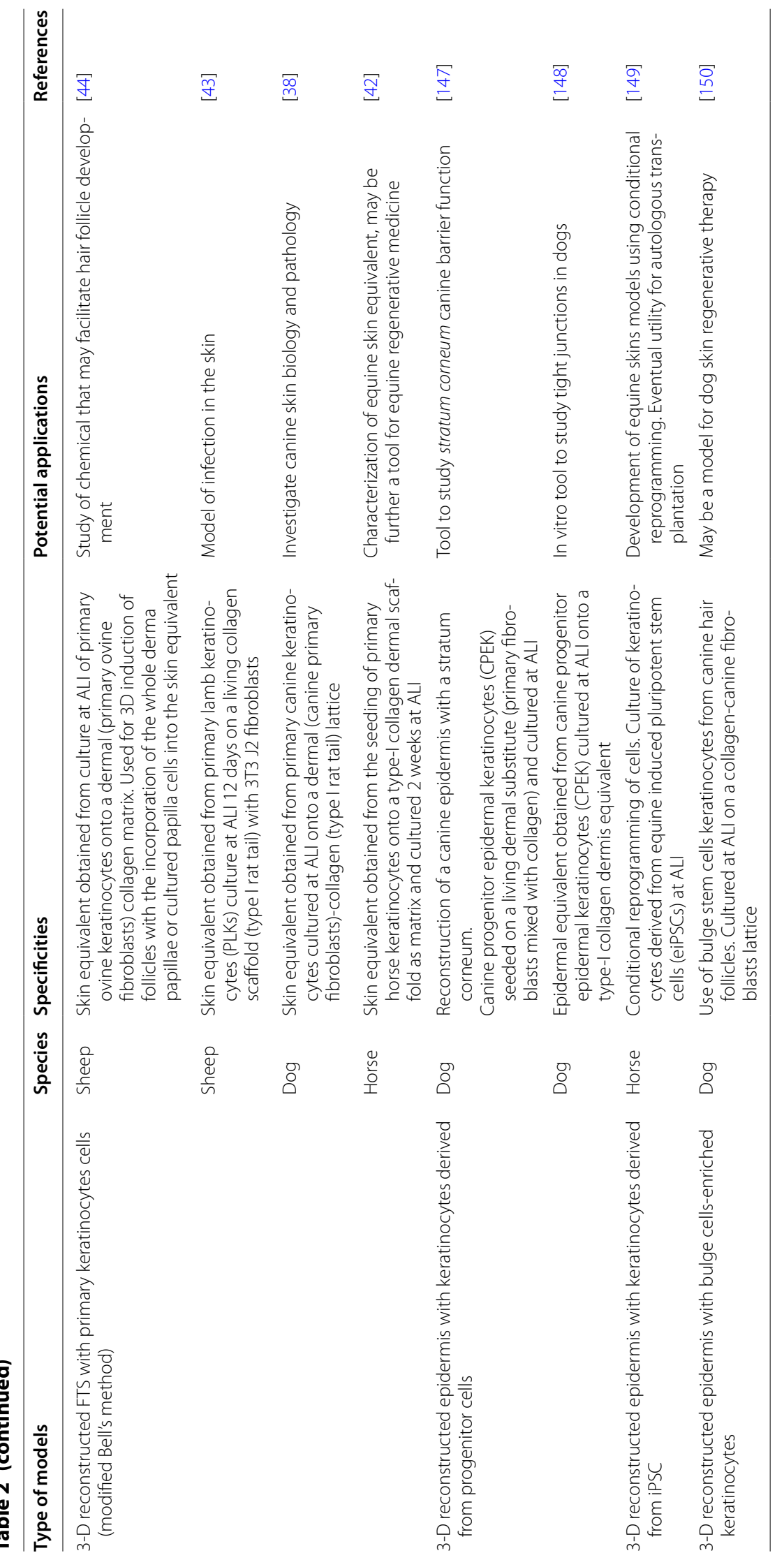


$72 \mathrm{~h}$ [136]. Pig skin initially elicited the most interest as human skin model until the availability of human RHE and FTS [133]. Domestic pig skin was an interesting model due to its similarity with human skin in term of lipids composition and permeability [137-139] and the low amount of hair [140]. Pig skin biopsies were used for testing drug/products either (i) directly on freshly collected skins or (ii) after a time of culture of the skin for 2 weeks. Protocols using skin collected from other parts of the pigs' body or shaving down the dermis so as to render skin thickness more representative of human skin (e.g. [141]) have been reported. For chicken, skin explants and skin culture from chick embryos have been used. Chicken skin explants can be cultivated at the ALI on a grid or an insert [142], on semi-solid agar, or grafted on a chorioallantoic membrane (CAM) [22]. Note that the grafted method on CAM is also feasible with human or mouse explants [22, 143] (Table 1). Chicken skin explants were frequently used in the past to study skin appendage development (for e.g. [22, 144]). Two canine skins explant models which could be maintained viable for 2 weeks were recently published $[133,145]$.

\subsection{Skin equivalents in animals}

To date, fewer than a dozen skin equivalent 3D cultures have been published for domestic animals, and only for dog, horse, and sheep (Table 2). In these models, methods developed with human skin were adapted to veterinary species. Reconstructed epidermis was obtained for dog and horse. For that, primary isolated keratinocytes were cultured onto: (i) pig acellular DED matrix [39], or (ii) an inert transwell matrix [41]. Well-differentiated FTS equivalents were also obtain with a modification of the Bell's method (see above paragraph 2.3) for four species: ovine [43, 44], canine [38, 146], feline [40], and equine [42]. Of note, Watson incorporated efficiently whole derma papilla or cultured papilla cells into reconstructed ovine skin [44]. Other protocols utilized long-term progenitor epidermal cells lines. Canine 3D organotypic skin models were obtained using canine progenitor epidermal keratinocytes onto an acellular collagen gel layer. Two studies based on this protocol produced canine epidermal equivalent with a well-defined cornified layer [147, 148]. Keratinocytes derived iPSC [149] and bulge cellsenriched keratinocytes from dog hair-follicles [150] have also been used in reconstructed equine and canine epidermis, respectively. As of today, there are no skin equivalents for birds.

\subsection{The future of 3D skin models in veterinary medicine}

As mentioned above, the availability of 3D animal skin models for veterinary purposes (health, well-being, research) is very limited. With the remarkable development of human skin equivalents, animal skin models are no longer models for humans, but may benefit from human skin model developments.

The animal 3D skin models are still important for comparative biology and for several skin diseases, notably dermatitis (e.g., Staphylococcus aureus skin infection and atopic dermatitis in dog). In different species, such models could be used to investigate the effects of microbiota on skin permeability. In the vaccinology field, they may become more important in the future to study transcutaneous delivery of antigens for vaccination, a new promising mode of vaccine administration to animals. Such skin models may also help develop molecule administration through the skin for a general effect. Several antiparasitic molecules are already delivered by such a way ("spot on" administration) with great success (e.g., Fipronil against fleas and ticks in cats and dogs). Lastly, these animal models could allow to evaluate the impact of toxic products for animal skin, notably for animals bred for human consumption and for food products containing skin components.

Skin 3D models were previously shown to be valuable models to study virus/skin interactions, notably with herpesviruses (e.g., Varicella Zoster Virus and Herpes Simplex Virus 1) [151, 152]. Our research interests focus on the Marek's disease virus, an oncogenic avian herpesvirus that is persistently shed into the environment by infected chickens, whether vaccinated or not. This virus is produced by the epidermal cells of the feather follicles wall. The feather follicle epithelium is the only tissue capable of producing tremendous amounts of infectious mature virions. The ultimate goal in poultry production is to stop virus shedding in skin danders in order to eradicate the disease. Compared to live animal experimentation, using $3 \mathrm{D}$ chicken skin models would be useful as they allow various manipulations (e.g., addition of drugs, gene overexpression, gene knock-in or knock-out) do not necessitate an animal facility, and are more acceptable in term of ethics. Therefore, a reconstituted chicken epidermis or FTS model would offer a better opportunity to identify cellular and viral molecular determinants involved in virions shedding and to develop new strategies to counteract it.

\section{Conclusion}

The available protocols for 3D skin in human are plethoric and still expanding. They are already used for many applications in cosmetology and toxicology and are regularly adapted to develop new in vitro models of skin diseases. Importantly, these models represent great alternatives to animal experiments for skin testing. 
Although the number of such protocols are still limited in domestic animals, their feasibility with methods commonly used in humans was recently demonstrated in a few veterinary species. The development of such new models may greatly help the study of skin diseases as well as the examination of transcutaneous delivery of pharmaceutical molecules and vaccine antigens.

\section{Abbreviations}

aDED: Acellular de-epidermized dermis; ALI: Air-liquid interface; DED: Deepidermized dermis; DS: Dermal substitute; FTS: Full-thickness skin; iPSC: Inducible pluripotent stem cells; RHE: Reconstructed human epidermis; UV: Ultraviolet; 2D: Two-dimensional; 3D: Three-dimensional.

\section{Acknowledgments}

We are very grateful to Prof. Danielle Dhouailly for her expert comments on the manuscript.

\section{Authors' contributions}

$L S$ and $C D$ and wrote the manuscript. Both authors read and approved the final manuscript.

\section{Funding}

This work was supported by the Region Centre Val de Loire IA/FEDER grant to C.Denesvre (ANIMALT project).

\section{Availability of data and materials}

Not applicable.

\section{Ethics approvals and consent to participate}

Not applicable.

\section{Consent for publication}

All authors consent for publication.

\section{Competing interests}

The authors declare that they have no competing interests.

Received: 19 October 2020 Accepted: 29 December 2020 Published online: 15 February 2021

\section{References}

1. Randall MJ, Jungel A, Rimann M, Wuertz-Kozak K (2018) Advances in the biofabrication of 3D skin in vitro: healthy and pathological models. Front Bioeng Biotechnol 6:154

2. Senoo M (2013) Epidermal stem cells in homeostasis and wound repair of the skin. Adv Wound Care (New Rochelle) 2:273-282

3. Candi E, Schmidt R, Melino G (2005) The cornified envelope: a model of cell death in the skin. Nat Rev Mol Cell Biol 6:328-340

4. Halprin KM (1972) Epidermal "turnover time" —a re-examination. Br J Dermatol 86:14-19

5. Potten CS, Saffhill R, Maibach HI (1987) Measurement of the transit time for cells through the epidermis and stratum corneum of the mouse and guinea-pig. Cell Tissue Kinet 20:461-472

6. Nishimura EK (2011) Melanocyte stem cells: a melanocyte reservoir in hair follicles for hair and skin pigmentation. Pigment Cell Melanoma Res 24:401-410

7. Lin SJ, Foley J, Jiang TX, Yeh CY, Wu P, Foley A, Yen CM, Huang YC, Cheng HC, Chen CF, Reeder B, Jee SH, Widelitz RB, Chuong CM (2013) Topology of feather melanocyte progenitor niche allows complex pigment patterns to emerge. Science 340:1442-1445

8. Hoath SB, Leahy DG (2003) The organization of human epidermis: functional epidermal units and phi proportionality. J Invest Dermatol 121:1440-1446
9. Nestle FO, Di Meglio P, Qin JZ, Nickoloff BJ (2009) Skin immune sentinels in health and disease. Nat Rev Immunol 9:679-691

10. Combadiere B, Liard C (2011) Transcutaneous and intradermal vaccination. Hum Vaccin 7:811-827

11. Matejuk A (2018) Skin Immunity. Arch Immunol Ther Exp (Warsz) $66: 45-54$

12. Guttman-Yassky E, Zhou L, Krueger JG (2019) The skin as an immune organ: Tolerance versus effector responses and applications to food allergy and hypersensitivity reactions. J Allergy Clin Immunol 144:362-374

13. Byrd AL, Belkaid Y, Segre JA (2018) The human skin microbiome. Nat Rev Microbiol 16:143-155

14. Rodrigues Hoffmann A, Patterson AP, Diesel A, Lawhon SD, Ly HJ, Elkins Stephenson C, Mansell J, Steiner JM, Dowd SE, Olivry T, Suchodolski JS (2014) The skin microbiome in healthy and allergic dogs. PLOS ONE 9:e83197

15. Denesvre C, Dumarest M, Remy S, Gourichon D, Eloit M (2015) Chicken skin virome analyzed by high-throughput sequencing shows a composition highly different from human skin. Virus Genes 51:209-216

16. Chen YE, Fischbach MA, Belkaid Y (2018) Skin microbiota-host interactions. Nature 553:427-436

17. Mauldin EA, Peters-Kennedy J (2015) Integumentary system. In: Maxie $\mathrm{G}$ (ed) Pathology of domestic animals, 6th edn. Elsevier, Hoboken, pp 509-736.e501

18. Dhouailly D, Oftedal O (2016) Integument and associated integumentary appendages. In: Baldock RBJ, Duncan D, Moriss-Kay G (eds) Kaufman's atlas of mouse development supplement. Academic Press, Cambridge, pp 147-164

19. Dupin E, Calloni G, Real C, Goncalves-Trentin A, Le Douarin NM (2007) Neural crest progenitors and stem cells. C R Biol 330:521-529

20. Strunk D, Egger C, Leitner G, Hanau D, Stingl G (1997) A skin homing molecule defines the langerhans cell progenitor in human peripheral blood. J Exp Med 185:1131-1136

21. Collin M, Milne P (2016) Langerhans cell origin and regulation. Curr Opin Hematol 23:28-35

22. Dhouailly D (1973) Dermo-epidermal interactions between birds and mammals: differentiation of cutaneous appendages. J Embryol Exp Morphol 30:587-603

23. Mlitz V, Strasser B, Jaeger K, Hermann M, Ghannadan M, Buchberger M, Alibardi L, Tschachler E, Eckhart L (2014) Trichohyalin-like proteins have evolutionarily conserved roles in the morphogenesis of skin appendages. J Invest Dermatol 134:2685-2692

24. Matoltsy AG (1969) Keratinization of the avian epidermis: an ultrastructural study of the newborn chick skin. J Ultrastruct Res 29:438-458

25. Vanhoutteghem A, Djian P, Green H (2008) Ancient origin of the gene encoding involucrin, a precursor of the cross-linked envelope of epidermis and related epithelia. Proc Natl Acad Sci USA 105:15481-15486

26. Couteaudier M, Trapp-Fragnet L, Auger N, Courvoisier K, Pain B, Denesvre C, Vautherot JF (2015) Derivation of keratinocytes from chicken embryonic stem cells: establishment and characterization of differentiated proliferative cell populations. Stem Cell Res 14:224-237

27. Ortolani-Machado C, De Freitas P, Borges ME, Faraco C (2008) Special features of dermal melanocytes in white silky chicken embryos. Anat Rec (Hoboken) 291:55-64

28. Lucas AM, Stettenheim PR (1972) Avian Anatomy Integument. Agric Handb 362:346-629

29. Schneider MR (2015) Fifty years of the asebia mouse: origins, insights and contemporary developments. Exp Dermatol 24:340-341

30. Holthaus KB, Eckhart L, Dalla Valle L, Alibardi L (2018) Review: Evolution and diversification of corneous beta-proteins, the characteristic epidermal proteins of reptiles and birds. J Exp Zool B Mol Dev Evol 330:438-453

31. Ehrlich F, Fischer $\mathrm{H}$, Langbein L, Praetzel-Wunder S, Ebner B, Figlak K, Weissenbacher A, Sipos W, Tschachler E، Eckhart L (2019) Differential evolution of the epidermal keratin cytoskeleton in terrestrial and aquatic mammals. Mol Biol Evol 36:328-340

32. Cotsarelis G, Sun TT, Lavker RM (1990) Label-retaining cells reside in the bulge area of pilosebaceous unit: implications for follicular stem cells, hair cycle, and skin carcinogenesis. Cell 61:1329-1337

33. Fuchs $E$ (2009) Finding one's niche in the skin. Cell Stem Cell 4:499-502 
34. Hsu YC, Li L, Fuchs E (2014) Emerging interactions between skin stem cells and their niches. Nat Med 20:847-856

35. Watt FM (1998) Epidermal stem cells: markers, patterning and the control of stem cell fate. Philos Trans R Soc Lond B Biol Sci 353:831-837

36. Green H, Kehinde O, Thomas J (1979) Growth of cultured human epidermal cells into multiple epithelia suitable for grafting. Proc Natl Acad Sci U S A 76:5665-5668

37. Mascre G, Dekoninck S, Drogat B, Youssef KK, Brohee S, Sotiropoulou PA, Simons BD, Blanpain C (2012) Distinct contribution of stem and progenitor cells to epidermal maintenance. Nature 489:257-262

38. Serra M, Brazis P, Puigdemont A, Fondevila D, Romano V, Torre C, Ferrer $L$ (2007) Development and characterization of a canine skin equivalent. Exp Dermatol 16:135-142

39. Cerrato S, Brazis P, Meana A, Fondevila D, Puigdemont A (2012) In vitro development and characterization of canine epidermis on a porcine acellular dermal matrix. Vet J 193:503-507

40. Tabart J, Baldo A, Vermout S, Nusgens B, Lapiere C, Losson B, Mignon B (2007) Reconstructed interfollicular feline epidermis as a model for Microsporum canis dermatophytosis. J Med Microbiol 56:971-975

41. Sharma R, Barakzai SZ, Taylor SE, Donadeu FX (2016) Epidermal-like architecture obtained from equine keratinocytes in three-dimensional cultures. J Tissue Eng Regen Med 10:627-636

42. Cerrato S, Ramio-Lluch L, Brazis P, Rabanal RM, Fondevila D, Puigdemont A (2014) Development and characterization of an equine skin-equivalent model. Vet Dermatol 25:475-e477

43. Scagliarini A, Dal Pozzo F, Gallina L, Guercio A, De Clerca E, Snoeck R, Andrei G (2005) Ovine skin organotypic cultures applied to the ex vivo study of orf virus infection. Vet Res Commun 29(Suppl 2):245-247

44. Watson SA, Pisansarakit P, Moore GP (1994) Sheep vibrissa dermal papillae induce hair follicle formation in heterotypic skin equivalents. $\mathrm{Br} J$ Dermatol 131:827-835

45. Breidahl AF, Judson RT, Dumble LJ, Clunie GJ (1990) In vitro culture of disaggregated rabbit keratinocytes. Immunol Cell Biol 68(Pt 2):119-126

46. Vanhoutteghem A, Londero T, Djian P, Ghinea N (2004) Serial cultivation of chicken keratinocytes, a composite cell type that accumulates lipids and synthesizes a novel beta-keratin. Differentiation 72:123-137

47. Coraux C, Hilmi C, Rouleau M, Spadafora A, Hinnrasky J, Ortonne JP, Dani C, Aberdam D (2003) Reconstituted skin from murine embryonic stem cells. Curr Biol 13:849-853

48. Guenou H, Nissan X, Larcher F, Feteira J, Lemaitre G, Saidani M, Del Rio M, Barrault CC, Bernard FX, Peschanski M, Baldeschi C, Waksman G (2009) Human embryonic stem-cell derivatives for full reconstruction of the pluristratified epidermis: a preclinical study. Lancet 374:1745-1753

49. Aguiar C, Therrien J, Lemire P, Segura M, Smith LC, Theoret CL (2016) Differentiation of equine induced pluripotent stem cells into a keratinocyte lineage. Equine Vet J 48:338-345

50. Toma JG, Akhavan M, Fernandes KJ, Barnabe-Heider F, Sadikot A, Kaplan DR, Miller FD (2001) Isolation of multipotent adult stem cells from the dermis of mammalian skin. Nat Cell Biol 3:778-784

51. Driskell RR, Clavel C, Rendl M, Watt FM (2011) Hair follicle dermal papilla cells at a glance. J Cell Sci 124:1179-1182

52. Lavker RM, Sun TT, Oshima $H$, Barrandon $Y$, Akiyama M, Ferraris C, Chevalier G, Favier B, Jahoda CA, Dhouailly D, Panteleyev AA, Christiano AM (2003) Hair follicle stem cells. J Investig Dermatol Symp Proc 8:28-38

53. Blanpain C, Lowry WE, Geoghegan A, Polak L, Fuchs E (2004) Selfrenewal, multipotency, and the existence of two cell populations within an epithelial stem cell niche. Cell 118:635-648

54. Ohyama M (2007) Hair follicle bulge: a fascinating reservoir of epithelial stem cells. J Dermatol Sci 46:81-89

55. Ito M, Liu Y, Yang Z, Nguyen J, Liang F, Morris RJ, Cotsarelis G (2005) Stem cells in the hair follicle bulge contribute to wound repair but not to homeostasis of the epidermis. Nat Med 11:1351-1354

56. Amoh Y, Hoffman RM (2017) Hair follicle-associated-pluripotent (HAP) stem cells. Cell Cycle 16:2169-2175

57. Plikus MV, Gay DL, Treffeisen E, Wang A, Supapannachart RJ, Cotsarelis $\mathrm{G}$ (2012) Epithelial stem cells and implications for wound repair. Semin Cell Dev Biol 23:946-953

58. Ohyama M, Kobayashi T (2012) Isolation and characterization of stem cell-enriched human and canine hair follicle keratinocyte. In: Singh SR (ed) Somatic stem cells: methods and protocols. Springer, Berlin, pp 389-401

59. Gerhards NM, Sayar BS, Origgi FC, Galichet A, Muller EJ, Welle MM Wiener DJ (2016) Stem cell-associated marker expression in canine hair follicles. J Histochem Cytochem 64:190-204

60. de Castro RVG, Tavares MR, Bressan FF, Pieri NCG, Baracho Trindade Hill A, Souza AF, da Cruz RN, Martins DS, Ambrosio CE, Meirelles FV, Garcia JM (2018) In vitro identification of a stem cell population from canine hair follicle bulge region. Tissue Cell 50:43-50

61. Zhang H, Zhang S, Zhao H, Qiao J, Liu S, Deng Z, Lei X, Ning L, Cao Y, Zhao Y, Duan E (2015) Ovine hair follicle stem cells derived from single vibrissae reconstitute haired skin. Int J Mol Sci 16:17779-17797

62. Motlik J, Klima J, Dvorankova B, Smetana K Jr (2007) Porcine epidermal stem cells as a biomedical model for wound healing and normal/malignant epithelial cell propagation. Theriogenology 67:105-111

63. Yue Z, Jiang TX, Widelitz RB, Chuong CM (2005) Mapping stem cell activities in the feather follicle. Nature 438:1026-1029

64. Nishimura EK, Jordan SA, Oshima H, Yoshida H, Osawa M, Moriyama M, Jackson IJ, Barrandon Y, Miyachi Y, Nishikawa S (2002) Dominant role of the niche in melanocyte stem-cell fate determination. Nature 416:854-860

65. Jahoda CA (1992) Induction of follicle formation and hair growth by vibrissa dermal papillae implanted into rat ear wounds: vibrissa-type fibres are specified. Development 115:1103-1109

66. Michler JK, Hillmann A, Savkovic V, Mulling CKW (2018) Horse hair follicles: a novel dermal stem cell source for equine regenerative medicine. Cytometry A 93:104-114

67. Kim YM, Park YH, Lim JM, Jung H, Han JY (2017) Technical note: Induction of pluripotent stem cell-like cells from chicken feather follicle cells. J Anim Sci 95:3479-3486

68. Medawar PB (1948) The cultivation of adult mammalian skin epithelium in vitro. Q J Microsc Sci 89:187-196

69. Antoni D, Burckel H, Josset E, Noel G (2015) Three-dimensional cell culture: a breakthrough in vivo. Int J Mol Sci 16:5517-5527

70. Wheeler CE, Canby CM, Cawley EP (1957) Long-term tissue culture of epithelial-like cells from human skin. J Invest Dermatol 29:383-391 (discussion 391-382)

71. Rheinwald JG, Green H (1975) Serial cultivation of strains of human epidermal keratinocytes: the formation of keratinizing colonies from single cells. Cell 6:331-343

72. Johnen C, Steffen I, Beichelt D, Brautigam K, Witascheck T, Toman N, Moser V, Ottomann C, Hartmann B, Gerlach JC (2008) Culture of subconfluent human fibroblasts and keratinocytes using biodegradable transfer membranes. Burns 34:655-663

73. Lei TC, Virador VM, Vieira WD, Hearing VJ (2002) A melanocyte-keratinocyte coculture model to assess regulators of pigmentation in vitro. Anal Biochem 305:260-268

74. Lebonvallet N, Jeanmaire C, Danoux L, Sibille P, Pauly G, Misery L (2010) The evolution and use of skin explants: potential and limitations for dermatological research. Eur J Dermatol 20:671-684

75. Edmondson R, Broglie JJ, Adcock AF, Yang L (2014) Three-dimensional cell culture systems and their applications in drug discovery and cellbased biosensors. Assay Drug Dev Technol 12:207-218

76. Chanet S, Martin AC (2014) Mechanical force sensing in tissues. Prog Mol Biol Transl Sci 126:317-352

77. Lee J, Cuddihy MJ, Kotov NA (2008) Three-dimensional cell culture matrices: state of the art. Tissue Eng Part B Rev 14:61-86

78. Sun T, Jackson S, Haycock JW, MacNeil S (2006) Culture of skin cells in $3 \mathrm{D}$ rather than $2 \mathrm{D}$ improves their ability to survive exposure to cytotoxic agents. J Biotechnol 122:372-381

79. Abd E, Yousef SA, Pastore MN, Telaprolu K, Mohammed YH, Namjoshi S, Grice JE, Roberts MS (2016) Skin models for the testing of transdermal drugs. Clin Pharmacol 8:163-176

80. Khalil C (2018) Human skin explants an in vitro approach for assessing UVB induced damage. Toxicol In Vitro 53:193-199

81. Prunieras M (1979) Epidermal cell cultures as models for living epidermis. J Invest Dermatol 73:135-137

82. Coquette A, Poumay Y (2009) The reconstructed human epidermis models in fundamental research. Fundamentals of tissue engineering and regenerative medicine. Springer, Berlin, pp 967-976 
83. Prunieras M, Regnier M, Woodley D (1983) Methods for cultivation of keratinocytes with an air-liquid interface. J Invest Dermatol 81:28s-33s

84. Carroll JM, Moles JP (2000) A three-dimensional skin culture model for mouse keratinocytes: application to transgenic mouse keratinocytes. Exp Dermatol 9:20-24

85. Niehues H, Bouwstra JA, El Ghalbzouri A, Brandner JM, Zeeuwen P, van den Bogaard EH (2018) 3D skin models for 3R research: The potential of $3 \mathrm{D}$ reconstructed skin models to study skin barrier function. Exp Dermatol 27:501-511

86. Marques AP, Pirraco RRP, Cerqueira MT, Reis RL (2018) Skin tissue models. Elsevier/Academic Press, London

87. Chaudhari AA, Vig K, Baganizi DR, Sahu R, Dixit S, Dennis V, Singh SR, Pillai SR (2016) Future prospects for scaffolding methods and biomaterials in skin tissue engineering: a review. Int J Mol Sci 17:1974

88. Suhail S, Sardashti N, Jaiswal D, Rudraiah S, Misra M, Kumbar SG (2019) Engineered skin tissue equivalents for product evaluation and therapeutic applications. Biotechnol J 14:e1900022

89. Tinois E, Tiollier J, Gaucherand M, Dumas H, Tardy M, Thivolet J (1991) In vitro and post-transplantation differentiation of human keratinocytes grown on the human type IV collagen film of a bilayered dermal substitute. Exp Cell Res 193:310-319

90. Netzlaff F, Lehr CM, Wertz PW, Schaefer UF (2005) The human epidermis models EpiSkin, SkinEthic and EpiDerm: an evaluation of morphology and their suitability for testing phototoxicity, irritancy, corrosivity, and substance transport. Eur J Pharm Biopharm 60:167-178

91. Rosdy M, Clauss LC (1990) Terminal epidermal differentiation of human keratinocytes grown in chemically defined medium on inert filter substrates at the air-liquid interface. J Invest Dermatol 95:409-414

92. Poumay $Y$, Dupont F, Marcoux S, Leclercq-Smekens M, Herin M, Coquette A (2004) A simple reconstructed human epidermis: preparation of the culture model and utilization in in vitro studies. Arch Dermatol Res 296:203-211

93. Kandarova H, Liebsch M, Schmidt E, Genschow E, Traue D, Spielmann H, Meyer K, Steinhoff C, Tornier C, De Wever B, Rosdy M (2006) Assessment of the skin irritation potential of chemicals by using the SkinEthic reconstructed human epidermal model and the common skin irritation protocol evaluated in the ECVAM skin irritation validation study. Altern Lab Anim 34:393-406

94. Pohin M, Veaute C, Garnier J, Barrault C, Cronier L, Huguier V, Favot L, McHeik J, Bernard FX, Lecron JC, Morel F, Jegou JF (2018) Development of a new model of reconstituted mouse epidermis and characterization of its response to proinflammatory cytokines. J Tissue Eng Regen Med 12:e1098-e1107

95. Cohen C, Dossou KG, Rougier A, Roguet R (1994) Episkin: An in vitro model for the evaluation of phototoxicity and sunscreen photoprotective properties. Toxicol In Vitro 8:669-671

96. El Ghalbzouri A, Siamari R, Willemze R, Ponec M (2008) Leiden reconstructed human epidermal model as a tool for the evaluation of the skin corrosion and irritation potential according to the ECVAM guidelines. Toxicol In Vitro 22:1311-1320

97. Lee DY, Ahn HT, Cho KH (2000) A new skin equivalent model: dermal substrate that combines de-epidermized dermis with fibroblast-populated collagen matrix. J Dermatol Sci 23:132-137

98. El Ghalbzouri A, Jonkman MF, Dijkman R, Ponec M (2005) Basement membrane reconstruction in human skin equivalents is regulated by fibroblasts and/or exogenously activated keratinocytes. J Investig Dermatol 124:79-86

99. Bell E, Ehrlich HP, Sher S, Merrill C, Sarber R, Hull B, Nakatsuji T, Church D, Buttle DJ (1981) Development and use of a living skin equivalent. Plast Reconstr Surg 67:386-392

100. Bell E, Sher S, Hull B, Merrill C, Rosen S, Chamson A, Asselineau D, Dubertret L, Coulomb B, Lapiere C, Nusgens B, Neveux Y (1983) The reconstitution of living skin. J Invest Dermatol 81:2s-10s

101. Tsunenaga M, Kohno Y, Horii I, Yasumoto S, Huh NH, Tachikawa T, Yoshiki S, Kuroki T (1994) Growth and differentiation properties of normal and transformed human keratinocytes in organotypic culture. Jpn J Cancer Res 85:238-244

102. Ikuta S, Sekino N, Hara T, Saito Y, Chida K (2006) Mouse epidermal keratinocytes in three-dimensional organotypic coculture with dermal fibroblasts form a stratified sheet resembling skin. Biosci Biotechnol Biochem 70:2669-2675
103. Berthod F, Hayek D, Damour O, Collombel C (1993) Collagen synthesis by fibroblasts cultured within a collagen sponge. Biomaterials 14:749-754

104. Dallon JC, Ehrlich HP (2008) A review of fibroblast-populated collagen lattices. Wound Repair Regen 16:472-479

105. Grinnell F (2008) Fibroblast mechanics in three-dimensional collagen matrices. J Bodyw Mov Ther 12:191-193

106. Sheikholeslam M, Wright MEE, Jeschke MG, Amini-Nik S (2018) Biomaterials for Skin Substitutes. Adv Healthc Mater 7:1700897

107. Debels H, Hamdi M, Abberton K, Morrison W (2015) Dermal matrices and bioengineered skin substitutes: a critical review of current options. Plast Reconstr Surg Glob Open 3:e284

108. Auxenfans C, Fradette J, Lequeux C, Germain L, Kinikoglu B, Bechetoille N, Braye F, Auger FA, Damour O (2009) Evolution of three dimensional skin equivalent models reconstructed in vitro by tissue engineering. Eur J Dermatol 19:107-113

109. Reijnders CM, van Lier A, Roffel S, Kramer D, Scheper RJ, Gibbs S (2015) Development of a full-thickness human skin equivalent in vitro mode derived from TERT-immortalized keratinocytes and fibroblasts. Tissue Eng Part A 21:2448-2459

110. Choi M, Park M, Lee S, Lee JW, Cho MC, Noh M, Lee C (2017) Establishment of immortalized primary human foreskin keratinocytes and their application to toxicity assessment and three dimensional skin culture construction. Biomol Ther (Seoul) 25:296-307

111. Bilousova G, Chen J, Roop DR (2011) Differentiation of mouse induced pluripotent stem cells into a multipotent keratinocyte lineage. J Invest Dermatol 131:857-864

112. Itoh M, Kiuru M, Cairo MS, Christiano AM (2011) Generation of keratinocytes from normal and recessive dystrophic epidermolysis bullosainduced pluripotent stem cells. Proc Natl Acad Sci USA 108:8797-8802

113. Itoh M, Umegaki-Arao N, Guo Z, Liu L, Higgins CA, Christiano AM (2013) Generation of 3D skin equivalents fully reconstituted from human induced pluripotent stem cells (iPSCs). PLOS ONE 8:e77673

114. Nissan X, Larribere L, Saidani M, Hurbain I, Delevoye C, Feteira J, Lemaitre G, Peschanski M, Baldeschi C (2011) Functional melanocytes derived from human pluripotent stem cells engraft into pluristratified epidermis. Proc Natl Acad Sci USA 108:14861-14866

115. Hewitt KJ, Shamis Y, Hayman RB, Margvelashvili M, Dong S, Carlson MW, Garlick JA (2011) Epigenetic and phenotypic profile of fibroblasts derived from induced pluripotent stem cells. PLOS ONE 6:e17128

116. Ali N, Hosseini M, Vainio S, Taieb A, Cario-Andre M, Rezvani HR (2015) Skin equivalents: skin from reconstructions as models to study skin development and diseases. Br J Dermatol 173:391-403

117. Lee J, Rabbani CC, Gao H, Steinhart MR, Woodruff BM, Pflum ZE, Kim A, Heller S, Liu Y, Shipchandler TZ, Koehler KR (2020) Hair-bearing human skin generated entirely from pluripotent stem cells. Nature 582:399-404

118. Abaci HE, Guo Z, Doucet Y, Jackow J, Christiano A (2017) Next generation human skin constructs as advanced tools for drug development. Exp Biol Med (Maywood) 242:1657-1668

119. Miyazaki H, Tsunoi Y, Akagi T, Sato S, Akashi M, Saitoh D (2019) A novel strategy to engineer pre-vascularized 3-dimensional skin substitutes to achieve efficient, functional engraftment. Sci Rep 9:7797

120. Chau DY, Johnson C, MacNeil S, Haycock JW, Ghaemmaghami AM (2013) The development of a 3D immunocompetent model of human skin. Biofabrication 5:035011

121. Archambault M, Yaar M, Gilchrest BA (1995) Keratinocytes and fibroblasts in a human skin equivalent model enhance melanocyte survival and melanin synthesis after ultraviolet irradiation. J Invest Dermatol 104:859-867

122. Huber B, Czaja AM, Kluger PJ (2016) Influence of epidermal growth factor (EGF) and hydrocortisone on the co-culture of mature adipocytes and endothelial cells for vascularized adipose tissue engineering. Cell Biol Int 40:569-578

123. van den Bogaard EH, Tjabringa GS, Joosten I, Vonk-Bergers $M$, van Rijssen E, Tijssen HJ, Erkens M, Schalkwijk J, Koenen H (2014) Crosstalk between keratinocytes and T cells in a 3D microenvironment: a model to study inflammatory skin diseases. J Invest Dermatol 134:719-727

124. Regnier M, Staquet MJ, Schmitt D, Schmidt R (1997) Integration of Langerhans cells into a pigmented reconstructed human epidermis. J Invest Dermatol 109:510-512 
125. Bechetoille N, Dezutter-Dambuyant C, Damour O, Andre V, Orly I, Perrier E (2007) Effects of solar ultraviolet radiation on engineered human skin equivalent containing both Langerhans cells and dermal dendritic cells. Tissue Eng 13:2667-2679

126. Choudhury S, Das A (2020) Advances in generation of three-dimensional skin equivalents: pre-clinical studies to clinical therapies. Cytotherapy. https://doi.org/10.1016/j.jcyt.2020.10.001

127. Hill DS, Robinson ND, Caley MP, Chen M, O’Toole EA, Armstrong JL, Przyborski S, Lovat PE (2015) A novel fully humanized 3D skin equivalent to model early melanoma invasion. Mol Cancer Ther 14:2665-2673

128. Klicks J, Molitor E, Ertongur-Fauth T, Rudolf R, Hafner M (2017) In vitro skin three-dimensional models and their applications. J Cell Biotechnol 3:21-39

129. Li J, Chen M, Fan X, Zhou H (2016) Recent advances in bioprinting techniques: approaches, applications and future prospects. J Transl Med 14:271

130. Retting KN, Nguyen DG (2018) Additive manufacturing in the development of 3D skin tissue Skin tissue models. Elsevier/Academic Press, London, pp 377-398

131. Marino D, Luginbuhl J, Scola S, Meuli M, Reichmann E (2014) Bioengineering dermo-epidermal skin grafts with blood and lymphatic capillaries. Sci Transl Med 6:221ra214

132. van den Broek LJ, Bergers L, Reijnders CMA, Gibbs S (2017) Progress and future prospectives in skin-on-chip development with emphasis on the use of different cell types and technical challenges. Stem Cell Rev Rep 13:418-429

133. Bauhammer I, Sacha M, Haltner E (2019) Establishment of an in vitro model of cultured viable human, porcine and canine skin and comparison of different media supplements. PeerJ 7:e7811

134. Kondo S, Hozumi Y, Aso K (1990) Long-term organ culture of rabbit skin: effect of EGF on epidermal structure in vitro. J Invest Dermatol 95:397-402

135. Hendry KA, Lancelott MJ, Knight CH, Kempson SA, Wilde CJ (1995) Protein synthesis in tissues cultured from the bovine hoof. Cell Tissue Res 281:93-99

136. Maboni G, Davenport R, Sessford K, Baiker K, Jensen TK, Blanchard AM, Wattegedera S, Entrican G, Totemeyer S (2017) A novel 3D skin explant model to study anaerobic bacterial infection. Front Cell Infect Microbiol 7:404

137. Herkenne C, Naik A, Kalia YN, Hadgraft J, Guy RH (2006) Pig ear skin ex vivo as a model for in vivo dermatopharmacokinetic studies in man. Pharm Res 23:1850-1856

138. Bacqueville D, Mavon A (2009) Comparative analysis of solar radiationinduced cellular damage between ex vivo porcine skin organ culture and in vitro reconstructed human epidermis. Int J Cosmet Sci 31:293-302

139. Flaten GE, Palac Z, Engesland A, Filipovic-Grcic J, Vanic Z, Skalko-Basnet $N$ (2015) In vitro skin models as a tool in optimization of drug formulation. Eur J Pharm Sci 75:10-24

140. Meyer W, Schwarz R, Neurand K (1978) The skin of domestic mammals as a model for the human skin, with special reference to the domestic pig. Curr Probl Dermatol 7:39-52
141. Dame MK, Spahlinger DM, DaSilva M, Perone P, Dunstan R, Varani J (2008) Establishment and characteristics of Gottingen minipig skin in organ culture and monolayer cell culture: relevance to drug safety testing. Vitro Cell Dev Biol Anim 44:245-252

142. Chuong CM (2000) Skin morphogenesis. Embryonic chicken skin explant cultures. Methods Mol Biol 136:101-106

143. Nowak-Sliwinska P, Segura T, Iruela-Arispe ML (2014) The chicken chorioallantoic membrane model in biology, medicine and bioengineering. Angiogenesis 17:779-804

144. Hughes MW, Wu P, Jiang TX, Lin SJ, Dong CY, Li A, Hsieh FJ, Widelitz RB, Chuong CM (2011) In search of the Golden Fleece: unraveling principles of morphogenesis by studying the integrative biology of skin appendages. Integr Biol (Camb) 3:388-407

145. Abramo F, Pirone A, Lenzi C, Vannozzi I, Della Valle MF, Miragliotta V (2016) Establishment of a 2-week canine skin organ culture model and its pharmacological modulation by epidermal growth factor and dexamethasone. Ann Anat 207:109-117

146. Yamazoe K, Miyamoto S, Hikosaka Y, Kitagawa K, Watanabe K, Sakai H, Kudo T (2007) Three-dimensional culture of keratinocytes and the formation of basement membrane for canine footpad substitute. JVet Med Sci 69:611-617

147. Yagihara H, Okumura T, Shiomi E, Shinozaki N, Kuroki S, Sasaki Y, Ito K, Ono K, Washizu T, Bonkobara M (2011) Reconstruction of stratum corneum in organotypically cultured canine keratinocyte-derived CPEK cells. Vet Res Commun 35:433-437

148. Teramoto K, Asahina R, Nishida H, Kamishina H, Maeda S (2018) Expression of ZO-1 and claudin-1 in a 3D epidermal equivalent using canine progenitor epidermal keratinocytes. Vet Dermatol. 29:288-e98

149. Alkhilaiwi F, Wang L, Zhou D, Raudsepp T, Ghosh S, Paul S, PalechorCeron N, Brandt S, Luff J, Liu X, Schlegel R, Yuan H (2018) Long-term expansion of primary equine keratinocytes that maintain the ability to differentiate into stratified epidermis. Stem Cell Res Ther 9:181

150. Kobayashi T, Enomoto K, Wang YH, Yoon JS, Okamura R, Ide K, Ohyama M, Nishiyama T, Iwasaki T, Nishifuji K (2013) Epidermal structure created by canine hair follicle keratinocytes enriched with bulge cells in a threedimensional skin equivalent model in vitro: implications for regenerative therapy of canine epidermis. Vet Dermatol 24:e19-20

151. Jarosinski KW, Carpenter JE, Buckingham EM, Jackson W, Knudtson K, Moffat JF, Kita H, Grose C (2018) Cellular stress response to varicella-zoster virus infection of human skin includes highly elevated interleukin-6 expression. Open Forum Infect Dis 5:ofy118

152. Tajpara P, Mildner M, Schmidt R, Vierhapper M, Matiasek J, PopowKraupp T, Schuster C, Elbe-Burger A (2019) A preclinical model for studying herpes simplex virus infection. J Invest Dermatol 139:673-682

\section{Publisher's Note}

Springer Nature remains neutral with regard to jurisdictional claims in published maps and institutional affiliations.

Ready to submit your research? Choose BMC and benefit from:

- fast, convenient online submission

- thorough peer review by experienced researchers in your field

- rapid publication on acceptance

- support for research data, including large and complex data types

- gold Open Access which fosters wider collaboration and increased citations

- maximum visibility for your research: over $100 \mathrm{M}$ website views per year

At BMC, research is always in progress.

Learn more biomedcentral.com/submissions 